\title{
Stratigraphic Framework of Cambrian and Ordovician Rocks in the Central Appalachian Basin From Medina County, Ohio, Through Southwestern and South- Central Pennsylvania to Hampshire County, West Virginia
}

By Robert T. Ryder, Anita G. Harris, and John E. Repetski

Revised and digitized by Robert D. Crangle, Jr.

Chapter E.2.2 of

Coal and Petroleum Resources in the Appalachian Basin:

Distribution, Geologic Framework, and Geochemical Character

Edited by Leslie F. Ruppert and Robert T. Ryder

Professional Paper 1708 
Suggested citation:

Ryder, R.T., Harris, A.G., and Repetski, J.E., 2014, Stratigraphic framework of Cambrian and Ordovician rocks in the central Appalachian basin from Medina County, Ohio, through southwestern and south-central Pennsylvania to Hampshire County, West Virginia, chap. E.2.2 of Ruppert, L.F., and Ryder, R.T., eds., Coal and petroleum resources in the Appalachian basin; Distribution, geologic framework, and geochemical character: U.S. Geological Survey Professional Paper 1708, 1 p., 1 40-p. pamphlet, 1 oversized sheet, http://dx.doi.org/10.3133/pp1708E.2.2. [This chapter is a re-release of U.S. Geological Survey Bulletin 1839-K, by Robert T. Ryder, Anita G. Harris, and John E. Repetski, 1992; online version 2.0 revised and digitized by Robert T. Crangle, Jr., 2003, available at http://pubs.usgs.gov/bul/b1839k/.] 


\title{
Stratigraphic Framework of Cambrian and Ordovician Rocks in the Central Appalachian Basin From Medina County, Ohio, Through Southwestern and South-Central Pennsylvania to Hampshire County, West Virginia
}

\author{
By Robert T. Ryder, ${ }^{1}$ Anita G. Harris, ${ }^{2}$ and John E. Repetski ${ }^{1}$
}

Revised and digitized by Robert D. Crangle, Jr. ${ }^{1}$

This chapter is a re-release of U.S. Geological Survey Bulletin 1839-K, of the same title, by Ryder and others (1992; online version 2.0 revised and digitized by Robert D. Crangle, Jr., 2003). It consists of one file of the report text as it appeared in USGS Bulletin 1839-K and a second file containing the cross section, figures 1 and 2, and tables 1 and 2 on one oversized sheet; the second file was digitized in 2003 as version 2.0 and also includes the gamma-ray well $\log$ traces.

To access the oversized plate, click here.

To access the text of the report, click here.

\section{Reference Cited}

Ryder, R.T., Harris, A.G., and Repetski, J.E., 1992, Stratigraphic framework of Cambrian and Ordovician rocks in the central Appalachian basin from Medina County, Ohio, through southwestern and south-central Pennsylvania to Hampshire County, West Virginia: U.S. Geological Survey Bulletin 1839-K, 40 p., 1 plate. (Revised and digitized by Robert D. Crangle, Jr., 2002; also available at http://pubs.usgs.gov/bul/b1839k/.)

${ }^{1}$ U.S. Geological Survey, Reston, Va.

${ }^{2}$ Deceased (formerly U.S. Geological Survey). 